\title{
ANALISIS NILAI KEADILAN RESTORATIF PADA PENERAPAN HUKUM ADAT DI INDONESIA
}

\author{
Destri Tsurayya Istiqamah \\ Lembaga Bantuan Hukum, Bandung \\ email: destristiqamah@gmail.com
}

disampaikan 29/5/18 - di-review 3/6/18 - diterima 25/6/18

DOI: $10.25123 /$ vej.2914

\begin{abstract}
Already in 2014, restorative justice as a distinct approach within the general criminal justice system had been used as the basis to treat child victims and offenders (the child protection Act of 2014). Nonetheless it is worth noticing that long before the promulgation of this Act, restorative justice has been used and is embedded in the living law of the Indonesian indigenous populations. This paper, using a descriptive analytical method, shall elaborate upon those traditional values found in the living law of the indigenous populations which resembles or reflects a restorative justice approach. In addition the author argues that this approach should also be used outside the limited scope of children criminal justice system.
\end{abstract}

Keywords:

Restorative justice, indigenous law, child victim and offender

\begin{abstract}
Abstrak
Kedilan restoratif sebagai suatu pendekatan khusus dalam sistem peradilan pidana umum diadopsi ke dalam Undang-Undang Perlindungan Anak 2014. Namun perlu dicermati bahwa jauh sebelum itu, bahkan sebelum zaman kolonial, pendekatan keadilan restoratif sudah lazim digunakan dalam penegakan hukum oleh masyarakat adat di Indonesia. Tulisan ini yang menggunakan pendekatan deskriptis analitis akan memaparkan nilai-nilai hukum adat yang mendekati atau merefleksikan pendekatan keadilan restorative. Satu usulan dari penulis adalah penerapan pendekatan ini seharusnya dibuka tidak hanya untuk penegakan hukum pidana anak.
\end{abstract}

Kata Kunci:

Keadilan restoratif, hukum adat, anak sebagai pelaku dan korban tindak pidana

\section{Pendahuluan}

Hukum merupakan suatu hal yang ada karena adanya masyarakat dimana kemudian perkembangan hukum itu sendiri juga mengikuti perkembangan masyarakat. Salah satu pilar hukum yang sampai saat ini terus menerus berkembang di Indonesia adalah hukum pidana. Istilah "pidana" merupakan istilah yang lebih khusus, yaitu menunjukkan sanksi dalam hukum pidana. Pidana adalah sebuah konsep dalam bidang hukum yang masih perlu penjelasan lebih lanjut untuk dapat memahami arti dan hakekatnya. Menurut Roeslan Saleh 
"pidana adalah reaksi atas delik, dan ini berwujud suatu nestapa yang dengan sengaja ditimpakan negara kepada pembuat delik itu."1

Salah satu alasan diterapkannya hukum pidana yakni dalam rangka upaya sebagai salah satu penanggulangan kejahatan. Emil Durkheim di dalam bukunya menyatakan bahwa kejahatan merupakan bagian yang tidak terpisahkan dari kehidupan manusia di dunia, segala aktivitas manusia baik politik, sosial dan ekonomi dapat menjadi kausa kejahatan, sehingga keberadaan kejahatan tidak perlu disesali, melainkan ditanggulangi, dan berusaha menekan kualitas serta kuantitas kejahatan serendah mungkin. ${ }^{2}$ Upaya penanggulangan kejahatan itu sendiri dapat ditempuh dengan berbagai cara, misalnya melalui penerapan hukum pidana, pencegahan tanpa pidana, dan mempengaruhi pandangan masyarakat terhadap kejahatan. ${ }^{3}$

Hukum Pidana sangat identik dengan konsep pemidanaan yang sifatnya memberikan penderitaan atau siksaan. Tujuan hukum pidana pada umumnya adalah untuk melindungi kepentingan orang perseorangan (individu) atau hakhak asasi manusia dan melindungi kepentingan-kepentingan masyarakat dan negara dengan perimbangan yang serasi dari kejahatan/tindakan tercela di satu fihak dan dari tindakan penguasa yang sewenang-wenang di lain fihak. ${ }^{4}$ Hukum pidana adalah hukum sanksi (bijzondere sanctierecht), sebab dengan bertumpu pada sanksi itulah hukum pidana difungsikan untuk menjamin keamanan, ketertiban dan keadilan. ${ }^{5}$

Di dalam hukum pidana, khususnya hukum pidana yang berlaku di Indonesia, dikenal beberapa jenis pemidanaan. Berdasarkan Pasal 10 KUHP jenis pemidanaan terdiri dari :

\footnotetext{
1 Marwan Effendy, Teori Hukum Dari Pespektif Kebijakan, Perbandingan dan Harmonisasi Hukum Pidana, Referensi ME Centre Group, Jakarta, 2014, hlm., 184

2 S. Sahabuddin, Jurnal Dinamika Hukum : Reorientasi Kebijakan Kriminal Dalam Menyelesaikan Kasus Ringan (Dari Due Process Model ke Reintegrative Model), Fakultas Hukum Universitas Jenderal Soedirman, Purwokerto, 2014, hlm.,162

3 Id., hlm, 162

4 E.Y, Kanter dan S.R Sianturi, Asas-asas Hukum Pidana di Indonesia dan Penerapannya, Storia Grafika, Jakarta, 2012, hlm. 55

5 M. Hamdan, Politik Hukum Pidana, PT. Raja Grafindo Persada, 1997, Jakarta, hlm., 131
} 
a. Pidana pokok :

1. Pidana mati

2. Pidana penjara

3. Pidana kurungan

4. Pidana denda

5. Pidana tutupan

b. Pidana tambahan :

1. Pencabutan hak-hak tertentu

2. Perampasan barang-barang tertentu

3. Pengumuman putusan hakim.

Dari seluruh jenis pemidanaan berdasarkan Pasal 10 KUHP, pelaksanaan pemidanaan yang paling sering dipraktekkan ialah pidana penjara dan kurungan. Hal ini disebabkan beberapa faktor, antara lain akibat kedudukan pidana denda dalam KUHP yang berlaku sekarang ini dirasakan kurang memenuhi rasa keadilan masyarakat. Di samping itu tidak dapat dinafikan bahwasanya pidana penjara saat ini telah "mendunia", seolah-olah kita tidak akan dapat hidup tenteram tanpa jenis pidana itu. ${ }^{6} \mathrm{Hal}$ ini berdampak pada penuh sesaknya lapas di 28 kantor wilayah di seluruh Indonesia, bahkan rencananya akan dibangun lapas-lapas baru di beberapa wilayah yang akan menghabiskan dana sebesar 1,6 triliun ${ }^{7}$. Kepala Biro Hukum dan Humas MA pada tahun 2013 memperhatikan bahwa penuhnya lapas diakibatkan banyaknya kasus-kasus yang sebetulnya tidak perlu sampai pada tingkatan kasasi, seperti di antaranya kasus-kasus tindak pidana ringan. Hal ini tentu tidak hanya berdampak pada masyarakat tetapi juga beban negara, mengingat bahwa beban biaya 1 (satu) orang di Lembaga Pemasyarakatan ratarata sebesar Rp. 50.000 per hari untuk biaya makan. ${ }^{8}$ Fenomena ini menunjukkan

6 M. Hamdan, supra no. 5, hlm. 129

7 Lihat Berita CNN Indonesia Penjara Penuh Sesak, Ratusan Kepala Lapas Mengadu ke Yasonna, Diunduh 2 Juni 2018, pkl 11.33

8 Lihat Berita Hukum Online, MA Keluhkan Pelaksanaan Perma Tipiring. Diunduh 1 Maret 2018, pkl. 00:14 
bahwa penerapan hukuman sanksi pidana badan di Indonesia masih sangat tinggi, bahkan untuk kasus-kasus ringan sekalipun.

Barda Nawawi Arief mengemukakan bahwa pidana penjara saat ini sedang mengalami 'masa krisis', karena termasuk jenis pidana yang kurang disukai. Banyak kritik tajam ditujukan terhadap jenis pidana perampasan kemerdekaan ini, baik dilihat dari sudut efektivitasnya maupun dilihat dari akibat-akibat lainnya menyertai atau berhubungan dengan dirampasnya kemerdekaan seseorang. ${ }^{9}$ Terdapat hal yang perlu digaris-bawahi, bahwa terlepas dari segalanya, secara jujur harus diakui bahwa, pidana perampasan kemerdekaan seperti pidana penjara ternyata membawa dampak negatif tidak saja bagi yang terkena, tetapi juga masyarakat. Bagi yang terkena, penderitaan tidak hanya dialami sendiri, tetapi juga bagi keluarganya dan orang-orang yang hidupnya tergantung pada terpidana. Bagi masyarakat, kerugian nampak dari sering timbulnya residivisme sebagai akibat penjatuhan pidana penjara, disamping biaya-biaya sosial yang banyak dikeluarkan untuk membiayai pelaksanaan pidana tersebut. ${ }^{10} \mathrm{Hal}$ demikian memperlihatkan bahwa pemberian sanksi hukuman badan tidaklah efektif untuk menjaga ketertiban masyarakat. Perlu adanya pergeseran pola pikir masyarakat untuk tidak mengidentikkan pemberian sanksi pidana badan dalam menghadapi penyimpangan prilaku di masyarakat. Salah satu konsep yang bisa diterapkan yakni dengan mendorong penerapan Restorative justice (keadilan restoratif).

Konsep keadilan Restoratif (Restorative Justice) ini memang berkembang atas pemikiran kritis dan kekecewaan terhadap konsep pemidanaan konvensional yang tidak efektif dan dipandang tidak humanis. Hal ini sejalan dengan pemikiran dari UNODC (United Nations Office on Drugs and Crime) yang menyatakan:

9 M. Hamdan, supra no. 5, hlm. 139

10 Muladi, Proyeksi Hukum Pidana Materiil Indonesia di Masa Datang, Universitas Diponegoro, Semarang, 1990, hlm. 23 
"Restorative justice can therefore be understood as a response to dissatisfaction and frustration with the fomal justice system."11

Di Indonesia konsep keadilan restoratif mulai berkembang dan diterapkan sebagai perundang-undangan sejak disahkannya Undang-undang No. 11 tahun 2012 tentang Sistem Peradilan Pidana Anak. Menurut keadilan restoratif, sistem peradilan pidana harus mendukung terciptanya masyarakat yang damai dan adil, sistem peradilan seharusnya ditujukan untuk menciptakan perdamaian, bukan untuk menghukum. ${ }^{12}$ Apabila diperhatikan, keadilan restoratif memiliki persamaan nilai dengan pidana adat, hukum pidana adat dijiwai oleh sifat kekeluargaan yang religius magis, dimana yang diutamakan bukanlah rasa keadilan perseorangan; melainkan rasa keadilan kekeluargaan, sehingga penyelesaian kasus yang dilakukan secara damai diyakini dapat membawa kerukunan (harmoni). Hukum pidana adat tidak bermaksud menunjukkan hukum dan hukuman apa yang harus dijatuhkan bila terjadi pelanggaran, tapi yang menjadi tujuannya adalah memulihkan kembali hukum yang pincang sebagai akibat terjadinya pelanggaran. ${ }^{13}$ Dengan demikian, penghukuman bukanlah hal dasar di dalam hukum adat maupun pada konsep keadilan restoratif.

Sebelum Indonesia dijajah Belanda, wilayah Indonesia terdiri dari beberapa kerajaan kecil dan besar. Pada saat itu, kehidupan masyarakat pada masing-masing kerajaan itu, diatur hanya dengan menggunakan hukum adat, karena dalam hidup bermasyarakat pasti diperlukan adanya hukum guna memenuhi kebutuhan hidup masyarakatnya. ${ }^{14}$ Mengingat hukum adat di Indonesia memiliki kesamaan nilai-nilai dengan konsep keadilan restoratif, sehingga dapat dikatakan bahwa akar nilai keadilan restoratif sudah diterapkan di

11 Justice Nicola Pain, dkk, Restorative Justice for Environmental Crime : an Antipodean Experince, International Union for Conservation of Nature Academy of Environmental Law Colloquium, Oslo Norway, 2016, hlm. 2

12 Marwan Effendy, Teori Hukum dari Perspektif Kebijakan, Perbandingan dan Harmonisasi Hukum Pidana. Jakarta : Referensi, 2014, hlm. 135

${ }^{13}$ Elwi Danil. Konstitusionalitas Penerapan Hukum Adat dalam Penyelesaian Perkara Pidana. Vol.9 No 3. Jurnal Konstitusi, Kepaniteraan dan Sekretariat Jenderal Mahkamah Konstitusi Republik Indonesia, Jakarta, 2012, hlm. 592

${ }^{14}$ St, Laksanto Utomo, Hukum Adat, Rajagrafindo Persada, 2016, Depok, hlm. 136 
Indonesia sebelum masa penjajahan. Hal ini kemudian membuka peluang perluasan penerapan keadilan restoratif yang tidak hanya dapat diterapkan kepada anak, tetapi juga orang dewasa.

Dengan demikian berdasarkan kritik-kritik terhadap praktek penghukuman di bidang pidana dan pandangan beberapa pakar terkait keadilan restoratif, maka melalui tulisan ini penulis ingin memaparkan penerapan keadilan restoratif di Indonesia dilihat dari beberapa aspek, seperti aspek peraturan perundang-undangan serta aspek sosiologis, khususnya dikaitkan dengan penerapan hukum adat di Indonesia. Selain itu juga di dalam tulisan ini akan dibahas pula mengenai tantangan dan hambatan apabila keadilan restoratif diterapkan di Indonesia.

\section{Pembahasan}

\section{Konsep dan Pengertian Keadilan Restoratif}

Pemidanaan yang secara umum diterapkan pada saat ini di Indonesia, atau kita sebut saja sebagai pemidanaan konvensional, masih bertujuan untuk menghukum dan masih memandang bahwa kejahatan tersebut dilakukan kepada Negara sebagai korban bukanlah pihak yang terkena langsung dampak dari kejahatan. Hal tersebut mengakibatkan sistem pemidanaan kita menghadapkan pelaku kejahatan dengan Negara. Hal ini menimbulkan stigma negatif sebagai narapidana melekat pada pelaku kejahatan. Dalam paradigma sistem peradilan pidana klasik, korban utama atas suatu tindak pidana yang timbul adalah negara, bukan korban dalam arti sesungguhnya. Lebih dari itu, korban yang sesungguhnya tak jarang justru dikorbankan kembali demi alasan pembuktian dalam proses peradilan pidana. 15

Para pendukung keadilan restoratif memandang upaya negara untuk menghukum dan mengawasi (sebagaimana pendekatan retributif) justru telah memicu orang melakukan kejahatan-kejahatan berikutnya, bukan membuat orang

\footnotetext{
15 Tim Departemen Kriminologi FISIP UI, Viktimologi Reparasi dan Kompensasi Korban Dalam Restorative Justice System, Lembaga Perlindungan Saksi dan Korban (LPSK), Jakarta, 2011, hlm. 29
} 
takut melakukan kejahatan. Permasalahan yang mendasar ialah sulitnya konsep keadilan restoratif ini diterima karena pandangan terhadap pelaku kejahatan tersebut digeneralisir dan dilandaskan oleh suatu kebencian, dendam atau ketidaksukaan bukan kepada kepentingan yang lebih luas di dalam pemberlakuan hukum pidana dengan mempertimbangkan keseimbangan antara kepentingan pelaku dan korban. ${ }^{16}$

Bertolak dari pemaparan di atas, pemidanaan konvensional dipandang tidak menjunjung keadilan karena hanya melibatkan langsung pelaku kejahatan dengan Negara. Padahal perlu diperhatikan bahwa tindakan kejahatan tidak hanya berdampak pada kedua belah pihak tersebut, melainkan juga korban yang terkena dampak langsung serta masyarakat sekitar. Douglas, Yrn merumuskan konsep Keadilan restoratif sebagai berikut :

"Restorative justice is criminal justice concept that views crime as a vialotion of people, not as a violation of the state, and creates an obligation to the victim and to the community to make things right. It focuses on the crimes harm rather than on the broken rule and emphasizes redress for the victim and community for the effects of the wrong doing over punishment imposed by the state. Restorative justice model may provide for appropriate dialogue, direct or indirect, between the victim and offender in the form of victim-offender mediation." (Keadilan restoratif adalah konsep peradilan pidana yang memandang tindak pidana sebagai kejahatan terhadap masyarakat bukan kejahatan terhadap negara dan untuk itu menciptakan kewajiban bagi korban dan masyarakat untuk memperbaikinya. Konsep ini berfokus akan bahayanya kejahatan daripada dilanggarnya suatu ketentuan serta menjabarkan hubungan antara korban dan masyarakat terhadap pelanggaran berkaitan dengan hukuman yang diterapkan oleh negara. Model keadilan restoratif memberikan dialog yang tepat, langsung maupun tidak langsung, antara korban dan pelaku kejahatan dalam bentuk mediasi antara korban-pelaku.) ${ }^{17}$

Pendapat dari Douglas, Yrn tersebut memberikan gambaran bahwa konsep keadilan restoratif mengedepankan dialog antara para pihak yakni pelaku kejahatan, korban langsung dari tindak kejahatan serta masyarakat terdampak.

16 Marwan Effendy, Supra no.12, hlm. 135

17 Id., hlm. 132 
Dialog yang dibangun bertujuan untuk mencari solusi bersama untuk menentukan tanggung jawab yang tepat atas tindakan yang dilakukan seseorang yang melakukan tindakan menyimpang. Hal ini sejalan dengan pendapat dari Tony Marshall yang menyatakan :

"Restorative justice is a prosess where by all the parties with a stake in a particular offence come together to resolve collectively how to deal with the aftermath of the offence and its implications for the future. (Peradilan restoratif ialah suatu proses yang semua pihak yang bertarung dalam suatu delik tertentu berkumpul bersama untuk memecahkan masalah secara kolektif bagaimana membuat persetujuan mengenai akibat (buruk) suatu delik dan implikasinya di masa depan.) ${ }^{18}$

Berikut pendapat dari Dignan:

"Restorative justice is a new frame work for responding to wrong doing and conflict that is rapidly gaining acceptance and support by aducational, legal, social work, and counceling professional and community groups. Restorative justice is a valued-based approach to responding to wrong doing and conflict, with a balanced focus on the person harmed, the person causing the harm, and the affected community" (Keadilan restoratif adalah kerangka kerja baru terhadap pelanggaran dan konflik, yang saat secara cepat dapat diterima dan didukung oleh pendidik, juris, pekerja sosial dan konsoling sosial serta kelompok masyarakat. Keadilan restoratif adalah berdasarkan pendekatan nilai sebagai respon dari pelanggaran dan konflik serta fokus yang bertumpu pada orang terkena akibat kejahatan, orang yang melakukan kejahatan dan pengaruhnya terhadap masyarakat). ${ }^{19}$

Seperti yang sudah dipaparkan sebelumnya bahwa konsep keadilan restoratif mengedepankan dialog yang dilakukan para pihak yang bersangkutan, seperti pelaku, korban dan masyarakat atau komunitas. Namun yang perlu diperhatikan yakni bahwa konsep dialogis ini perlu adanya kesadaran para pihak untuk menemukan solusi dan tindakan yang tepat atas dampak dari tindakan pelaku kejahatan tersebut. Bahkan di salah satu buku yang berjudul "Restorative Justice Philosophy to Practice" diterangkan bahwa di dalam dialog pada konsep

${ }^{18}$ Id., hlm. 131-132

${ }^{19}$ Id., hlm. 134 
keadilan restoratif ini pelaku tindak kejahatan harus menunjukkan rasa menyesal dan rasa bersalahnya kepada korban sehingga korban dapat melihat rasa penyesalan tersebut dan mengetahui lebih dalam latar belakang pelaku melakukan tindakan kejahatan. Dengan demikian konsep keadilan restoratif lebih berfokus pada tindakan, bukan pada pelaku. ${ }^{20}$ Konsep keadilan restoratif mengambil dan menyatukan banyak unsur dari praktek hukum yang telah berlaku dari retributive dan rehabilitative justice di abad yang lalu, dan memperkenalkan beberapa istilah-istilah baru. ${ }^{21}$ Seperti yang digambarkan di dalam tabel berikut ini :

\begin{tabular}{ll}
\multicolumn{1}{c}{\begin{tabular}{c}
\multicolumn{1}{c}{ Traditional Justice } \\
retributive and rehabilitative)
\end{tabular}} & \multicolumn{1}{c}{ Restorative Justice } \\
\hline Victims are peripheral to the process & Victims are central to the process \\
\hline $\begin{array}{l}\text { The focus is on punishing or on treating an } \\
\text { offender }\end{array}$ & $\begin{array}{l}\text { He focus is on repairing the harm between an } \\
\text { offender and victim, and perhaps also an } \\
\text { offender and a wider community }\end{array}$ \\
\hline The community is represented by the state & $\begin{array}{l}\text { Community members or organisations take a } \\
\text { more active role }\end{array}$ \\
\hline $\begin{array}{l}\text { The process is characterised by adversarial } \\
\text { relationships among the parties }\end{array}$ & $\begin{array}{l}\text { The process is characterised by dialogue and } \\
\text { negotiaion among the parties }\end{array}$ \\
\hline Tabel 122 &
\end{tabular}

Seperti yang telah dipaparkan sebelumnya bahwa keadilan restoratif mencakup proses antara para pihak untuk menentukan tanggung jawab pelaku terhadap korban, di sisi lain Mohammad Kemal Pratama menegaskan bahwa keadilan restoratif merupakan suatu ideologi yang menjunjung nilai-nilai hak asasi manusia, yakni menghormati martabat individu. Lebih lanjut ia memaparkan 3 (tiga) nilai yang dianut oleh keadilan restoratif, yakni ${ }^{23}$ :

1. Keadilan restoratif adalah sebuah ideologi, yang mengedepankan suatu proses yang melibatkan semua pihak yang terkait dengan terjadinya suatu tindak

${ }^{20}$ Intisari Kathleen Daly, Restorative Justice: Philosophy to practice, Ashgate, Dartmouth, USA, 2000, hlm 43

${ }^{21}$ Intisari Allison Morris and Warren Young, Restorative Justice: Philosophy to practice, Ashgate, Dartmouth, USA, 2000, hlm 13-20

22 Kathleen Daly, supra 20, hlm. 36

23 Intisari dari Mohammad Kemal Dermawan dan Mohammad Irvan Oli'i. Sosiologi Peradilan Pidana, FISIP UI dan Yayasan Obor Indonesia, Jakarta, 2015, hlm. 84 
pidana tertentu guna secara bersama-sama memecahkan masalah dan menghindari akibat negatif di masa yang akan datang. Ini adalah sebuah konsep payung bagi berbagai kegiatan nyata, seperti dilakukannya mediasi dan pertemuan korban-pelaku. Keadilan restoratif terang-terangan mengakui korban sebagai yang menderita kerugian akibat dari kejahatan. Banyak penulis menekankan bahwa keadilan restoratif adalah setiap proses yang memungkinkan para korban dan pelaku aktif berpartisipasi. Sebagai sebuah ideologi, keadilan restoratif ditandai oleh nilai-nilai dan prinsip-prinsip tertentu salah satu nilai tersebut adalah menghormati martabat individu. Ini adalah hak dari manusia, yang dapat ditemukan di universal declaration of Human Rights tahun 1948.

2. Nilai kedua dari keadilan restoratif adalah inklusi atau mendorong partisipasi korban dan pelaku.

3. Nilai ketiga adalah perbaikan, atau yang dikenal sebagai reparasi. Pelanggar didorong untuk bertanggungjawab dan mengakui konsekuensi dari perilaku mereka. Proses restoratif secara terang-terangan mengakui dan memvalidasi korban dan penderitaan mereka dan berusaha memperbaiki korban. Reparasi bisa mengambil berbagai bentuk dari kompensasi moneter untuk reparasi simbolis atau permintaan maaf. Pengakuan itu sendiri bisa mempercepat penyembuhan atau pemulihan korban.

Sehingga dengan demikian melalui tiga nilai tersebut dapat menggambarkan bahwa keadilan restoratif menjunjung tinggi nilai hak asasi manusia dan begitu memperhatikan sisi-sisi humanis dalam penerapannya. Penerapan keadilan restoratif lebih dari hanya sekedar proses dialogis untuk menyelesaikan permasalahan penyimpangan perilaku yang terjadi di masyarakat. Pada tabel di bawah ini akan diberikan gambaran-gambaran perbedaan antara konsep hukum pidana konvensional dengan konsep keadilan restoratif. Dimana akan terlihat konsep keadilan restoratif yang mengedepankan martabat manusia, berikut perdedaan-perbedaannya: 
Tabel: Perbedaan Konsep Keadilan Restoratif.

\begin{tabular}{|c|c|}
\hline Nilai & $\begin{array}{l}\text { - Keadilan restoratif memperhatikan hak asasi manusia dan juga } \\
\text { dampak sosial. Berbeda dengan hukum yang berlaku saat ini yang } \\
\text { lebih didasarkan pada etika dan kejahatan yang dilakukan pada } \\
\text { pelaku yang menempatkan hak hukum dan penghukuman pada } \\
\text { prioritas utama } \\
\text { - Adanya pemulihan pada keamanan, penghormatan, martabat dari } \\
\text { korban dan yang terpenting pengendalian terhadap perasaan atau } \\
\text { emosi korban } \\
\text { - Memunculkan rasa tanggungjawab pada pelaku atas perbuatan yang } \\
\text { telah ia lakukan serta dampak dari tindakan tersebut }\end{array}$ \\
\hline Proses & $\begin{array}{l}\text { Secara umum keadilan restoratif menyuguhkan proses yang lebih } \\
\text { informal dan lebih personal karena melibatkan pelaku dan korban secara } \\
\text { langsung. Berbeda dengan hukum pidana yang berlaku saat ini yang lebih } \\
\text { pada sesuatu yang bersifat ritual, prosedur yang formal dan rumit }\end{array}$ \\
\hline Hasil & $\begin{array}{l}\text { Berbeda dengan hukum pidana yang berlaku saat ini, yang lebih } \\
\text { mengedepankan pemberian sanksi hukuman, keadilan restoratif } \\
\text { berfokus pada permohonan maaf dari pelaku serta pemulihan lingkungan } \\
\text { masyarakat sekitarnya dengan cara pengembalian barang yang dicuri } \\
\text { atau menanggung luka yang dialami oleh korban. }\end{array}$ \\
\hline $\begin{array}{l}\text { Dari sudut pandang } \\
\text { korban }\end{array}$ & $\begin{array}{l}\text { Korban menempati posisi yang sangat penting dalam proses keadilan } \\
\text { restoratif. Berdasarkan penelitian hanya } 6 \% \text { korban yang tidak mau } \\
\text { bertemu dengan pelaku dan menyatakan bahwa meraka yang bertemu } \\
\text { dengan pelaku memiliki pengalaman yang positif karena dilibatkan } \\
\text { langsung untuk memahami tidak hanya kondisi pelaku saja tetapi juga } \\
\text { berhadapan dengan keluarga pelaku. Dalam upaya memahami secara } \\
\text { utuh permasalahan yang dihadapi oleh pelaku. }\end{array}$ \\
\hline $\begin{array}{l}\text { Dari sudut pandang } \\
\text { pelaku }\end{array}$ & $\begin{array}{l}\text { Pada peradilan pidana yang berlaku saat ini, pelibatan langsung pelaku } \\
\text { sangat sedikit. Seringkali pelaku berkomunikasi di pengadilan melalui } \\
\text { pengacaranya dan mereka dicegah untuk berkomunikasi langsung dengan } \\
\text { korban. Berbeda dengan keadilan restoratif yang melibatkan pelaku di } \\
\text { dalam proses dan berinteraksi dengan korban untuk berbicara terkait } \\
\text { kesalahan mereka dan membicarakan berbagai hal yang berkaitan dengan } \\
\text { kejahatannya tersebut. Untuk menunjukkan rasa bersalahnya dan } \\
\text { memohon maaf atas apa yang sudah mereka lakukan. Sehingga pelaku } \\
\text { berkontribusi juga dalam memunculkan keputusan akhir apa yang akan } \\
\text { disepakati antara pelaku dengan korban untuk mensikapi apa yang sudah } \\
\text { dilakukan oleh pelaku kepada korban. }\end{array}$ \\
\hline
\end{tabular}

Sumber: Intisari Allison Morris and Warren ${ }^{24}$

Dengan demikian konsep keadilan restoratif sangat berbeda dengan penerapan konsep pemidanaan yang saat ini berlaku umum di Indonesia. Sebetulnya konsep keadilan restoratif ini bukanlah hal yang baru dalam perkembangan hukum, khususnya hukum pidana nasional ataupun internasional.

Secara khusus hal ini akan dibahas pada sub pembahasan selanjutnya.

${ }^{24}$ Intisari Allison Morris and Warren Young, supra 21, hlm 13-20 


\section{Kasus-kasus yang Diselesaikan dengan Keadilan Restoratif}

Seperti yang telah dibahas sebelumnya bahwa di Indonesia konsep keadilan restoratif mulai diterapkan dan diberlakukan sebagai konsep hukum yang tertuang di dalam perundang-undangan sejak disahkannya Undang-undang No. 11 tahun 2012 tentang Sistem Peradilan Pidana Anak. Klausul keadilan restoratif' termuat di dalam Pasal 1 angka 6 yang berisi definisi dan diejawantahkan kemudian pada Pasal 5 ayat (1), Pasal 8 ayat (1), Pasal 93 huruf (d). Adapun definisi keadilan restoratif dalam Undang-undang tersebut yakni :

"Keadilan Restoratif adalah penyelesaian perkara tindak pidana dengan melibatkan pelaku, korban, keluarga pelaku/korban, dan pihak lain yang terkait untuk bersama-sama mencari penyelesaian yang adil dengan menekankan pemulihan kembali pada keadaan semula, dan bukan pembalasan."

Apabila melihat kembali pembahasan sebelumnya yang membahas terkait konsep dan istilah keadilan restoratif, istilah di atas memang melingkupi konsep dari keadilan restoratif. Di dalam Undang-undang No. 11 tahun 2012 pun dinyatakan secara tegas tentang pengutamaan penggunaan keadilan restoratif dalam sistem peradilan pidana anak (lihat Pasal 5 ayat (1) Undang-undang No. 11 Tahun 2012 tentang Sistem Peradilan Pidana Anak).

Penerapan serta aplikasi dari Undang-undang No. 11 Tahun 2012 tentang Sistem Peradilan Pidana Anak mengingatkan pada kasus di tahun 2014 yang menimpa anak dari musisi ternama di Indonesia Ahmad Dhani yang bernama AQJ. AQJ adalah seorang anak yang pada saat itu berumur 13 (tiga belas) tahun dan divonis bersalah karena kecelakaan lalulintas yang mengakibatkan beberapa orang terluka bahkan meninggal dunia. Pada kasus tersebut putusan pengadilan menyatakan "Menjatuhkan perintah agar terdakwa dikembalikan kepada orangtuanya, dengan beberapa pertimbangan bahwa terdakwa berkelakuan baik, sopan dan bukanlah anak nakal sehingga masih dapat dilakukan pembinaan. Selain itu telah terjadi perdamaian antar keluarga terdakwa dengan para korban. Dimana keluarga terdakwa menanggung biaya pengobatan korban yang terluka 
dan pemakaman bagi korban yang meninggal dunia. Bahkan keluarga terdakwa bersedia menanggung biaya pendidikan hingga perguruan tinggi bagi anak korban yang meninggal dunia. ${ }^{25}$ Kasus anak yang berhadapan dengan hukum lainnya yakni terkait siswi berumur 11 (sebelas) tahun yang membakar ruang kelas pada tahun 2016. Dimana pada tahap penyelidikan pun pihak kepolisian mendorong diterapkannya restorative justice. ${ }^{26}$

Penerapan keadilan restoratif yang terjadi di Negara lain tidak hanya diterapkan kepada anak-anak atau anak muda saja. Seperti salah satu contoh kasus yang terjadi di New Zealand pada tahun 1998 yang terkenal dengan sebutan "The Clotworthy Case". Kasus tersebut merupakan kasus perampokan serta penganiayaan yang dilakukan oleh Mr. Clotworthy, dimana pada penyelesaian kasus tersebut pelaku menyatakan bahwa ia melakukan kejahatan tersebut karena pengaruh alkohol dan ia pun sangat menyesali perbuatannya tersebut dengan bentuk ia akan membiayai seluruh biaya operasi korban akibat penganiayaan yang ia lakukan. Singkatnya, permintaan maaf dan tawaran pembiayaan operasi itu pun diterima oleh korban, dan pelaku melakukan kerja sosial sebanyak 200 jam. $^{27}$

Selain penerapan keadilan restoratif pada pemaparan di atas, Beberapa Negara seperti Australia dan New Zealand ${ }^{28}$ telah menggunakan penyelesaian dengan cara restorative justice pada kasus-kasus kejahatan lingkungan. Salah satu kasus lingkungan di Australia yang menerapkan keadilan restoratif yakni kasus suatu perusahaan yang bergerak dalam bidang pengelolaan limbah bernama SITA. Dimana SITA memiliki satu bidang tanah yang dipakai untuk pengelolaan limbah namun melewati batas izin lingkungan yang ditentukan karena dari tempat pengelolaan limbah tersebut mengeluarkan aroma yang sangat menyengat. Oleh karena itu, diadakan suatu pertemuan yang melibatkan beberapa pihak,

\footnotetext{
25 Berita hukumonline Hakim Perintahkan AQJ Dikembalikan Kepada Orang Tua, diunduh 30 April 2018, pkl. 23.11

26 Berita detiknews. Polisi Pakai Restorative Justice di Kasus Bocah Pembakar Ruang Kelas di Sukoharjo. Diunduh 30 April 2018, pkl 23.15

27 Intisari dari Allison Morris and Warren Young, supra 24, hlm 11-12

${ }^{28}$ Justice Nicola Pain, dkk, supra 11, hlm. 1
} 
termasuk SITA sendiri. Hasil dari pertemuan tersebut yakni bahwa SITA dituntut untuk melakukan beberapa hal, yakni29 :

1. Menyusun sebuah kajian literatur yang memaparkan temuan ilmiah tentang dampak dari bau yang dikeluarkan;

2. Memasang alat ukur infra-red yang dipantau melalui udara untuk mengidentifikasi daerah yang mengeluarkan bau;

3. Menanam pohon di sepanjang bagian batas ke Selatan;

4. Memberikan uang santunan kepada masyarakat sekitar sebesar 100.000 dolar; dan

5. Memberikan pernyataan rasa penyesalan secara resmi terhadap publik.

Dengan melihat beberapa contoh-contoh kasus yang telah menerapkan keadilan restoratif di atas, terlihat bahwa penerapan keadilan restoratif bukanlah bertujuan untuk memberikan penghukuman tetapi memberikan tanggung-jawab kepada pelaku kejahatan akibat perbuatan yang telah ia lakukan yang kemudian merugikan orang lain. Hal ini sejalan dengan salah satu prinsip keadilan restoratif yang disampaikan oleh Marian Liebmann, yang menyatakan bahwa :

"Pelaku bertanggungjawab atas apa yang telah ia lakukan. Pelaku kejahatan memang perlu 'dihukum'. Tetapi ini tidak sama dengan memikul tanggungjawab atas apa yang telah ia lakukan. Memikul tanggungjawab mengandung pengakuan dan kesadaran bahwa ia telah melakukan kejahatan, menjelaskan apa yang sebetulnya terjadi dan menanggung akibat dari perbuatannya, termasuk mengembalikan kerugian yang diakibatkan oleh tindakannya. Unsur ini merupakan titik tolak keadilan restoratif." 30

Pemberian penghukuman dan tanggungjawab inilah yang membedakan antara peradilan konvensional dengan keadilan restoratif. Mengingat bahwa keadilan restoratif memiliki semangat bukan untuk menghukum. Selain itu dampak positif yang dirasakan dari diterapkannya keadilan restoratif pun tidak

29 Id., hlm. 13-14

30 S. Atalim. Keadilan Restoratif Sebagai Kritik Inheren Terhadap Pengadilan Legal-Konvensional, Vol. 2 No. 2, Jurnal Rechtsvinding : Media Pembinaan Hukum Nasional berjudul Jakarta : Pusat Penelitian dan Pengembangan Sistem Hukum Nasional Badan Pembinaan Hukum Nasional Kementerian Hukum dan HAM RI, 2013, Hlm. 147-148 
hanya dialami oleh pelaku tindak kriminalnya saja, tetapi berdampak lebih luas yakni bagi korban serta masyarakat sekitar dengan mengedepankan dialog antar para pihak guna memahami kondisi satu sama lain.

Konsep penerapan keadilan restoratif dalam kasus-kasus di atas juga diterapkan oleh masyarakat kabupaten Maluku tengah yang memiliki bentuk tradisi adat dengan istilah Sasi. Sasi adalah suatu aturan yang disepakati bersama oleh anggota masyarakat adat untuk ditaati bersama oleh anggota masyarakat adat untuk ditaati bersama. Apabila Sasi ini dilanggar maka anggota masyarakat yang bersangkutan akan dikenai sanksi atau hukuman sesuai dengan peraturanperaturan Sasi yang telah disepakati. Dalam Sasi dikenal berbagai macam jenis sanksi, yakni sanksi denda, ganti rugi dan sanksi hukuman badan. Dalam penerapannya, dikenal juga sanksi kerja sosial yang merupakan pidana pengganti terhadap sanksi denda yang tidak dapat dibayar. Bentuk sanksi ini dikenal dengan nama kerja bakti berupa pembersihan kantor negeri/desa. Sanksi kerja bakti dapat digunakan sebagai pidana pengganti denda apabila pelaku tidak mampu membayar denda. Ide dasar dari sanksi kerja bakti ini adalah bahwa walaupun pelaku tidak mampu membayar denda, pelaku memiliki kesadaran dan keinginan untuk mempertanggungjawabkan kesalahannya, baik karena pelaku ingin menghindari kesialan yang ditimpakan oleh roh nenek moyang (nitu) atau tanah desa/negeri maupun karena pelaku ingin memulihkan nama baiknya yang telah tercela di masyarakat. 31

Di Minangkabau terdapat penerapan hukum adat dengan istilah "sumbangsalah". Contoh kasus dari penerapan hukum adat ini yakni apabila seorang janda didapati laki-laki yang setiap pagi turun dari rumah janda tersebut dan setelah mendapatkan teguran beberapa kali, perilaku "sumbang-salah" itu tetap berlangsung, akibatnya lembaga adat melaksanakan rapat dan memberi sanksi

\footnotetext{
31 Reimon Supusesa. Eksistensi Hukum Delik Adat Dalam Perspektif Pembaharuan Hukum Pidana di Maluku Tengah. Vol. 24 No. 1. Mimbar Hukum, Universitas Gadjah Mada, Yogyakarta, 2012, hlm 44-51
} 
adat kepada janda tersebut. Dimana sanksi yang diberikan yakni dibuang sepanjang adat. ${ }^{32}$

Konsep Sasi di Maluku Tengah dan sumbang-salah di Minangkabau merupakan beberapa contoh konkrit bahwa nilai keadilan restoratif diterapkan melalui hukum adat di Indonesia. Penyesuaian kemampuan pelaku dalam mempertanggungjawabkan perbuatannya serta penyelesaian berupa teguran terlebih dahulu menunjukkan bahwa hukum adat tidak berfokus kepada pelaku, tetapi lebih bertujuan pada keseimbangan lingkungan masyarakat. Hal ini senada dengan apa yang dikatakan oleh Ter Haar yang mengartikan suatu delik adat sebagai tiap-tiap gangguan terhadap keseimbangan, yang menyebabkan timbulnya suatu reaksi adat. Reaksi adat akan berusaha memulihkan keseimbangan yang terganggu. ${ }^{33}$ Nilai inilah yang merupakan nilai dari keadilan restoratif, yakni pemulihan bukan penghukuman.

\section{Konsep Keadilan Restoratif Dalam Hukum Adat Indonesia dan Penerapannya di Indonesia}

Hukum adat merupakan hukum asli masyarakat Indonesia, berakar pada adat istiadat atau merupakan pancaran nilai-nilai dasar budaya masyarakat Indonesia, yang berarti pula mengikat dan menemukan segala pikiran dan perasaan hukum orang-orang dalam masyarakat Indonesia. ${ }^{34}$ Hukum adat memiliki 3 (tiga) karakteristik, yakni : ia mengandung sifat yang sangat tradisional, dapat berubah, sanggup untuk menyesuaikan diri. Ciri khas ini menunjukkan bahwa walaupun hukum adat mempertahankan nilai-nilai tradisional yang dimiliknya, dalam waktu yang sama hukum adat pun dapat menerima perubahan yang memengaruhinya. Di sinilah letak fleksibilitas dari hukum adat. ${ }^{35}$ Fleksibilitas tersebutlah yang menyebabkan penerapan hukum adat

\footnotetext{
32 Intisari Elwi Danil., Supra no. 13, hlm. 587

33 Reimon Supusesa, Supra no. 31, hlm 48

${ }^{34}$ St, Laksanto Utomo, Supra no 14, hlm. 136

35 Yanis Maladi, Eksistensi Hukum Adat Dalam Konstitusi Negara Pascaamandemen. Vol. 22 No. 3. Mimbar Hukum, Universitas Gadjah Mada, Yogyakarta, 2010, hlm 456
} 
tidak bisa dilepaskan dari masyarakat, pasalnya hukum terus berkembang mengikuti perkembangan masyarakat itu sendiri.

Eva Achyani Zulfa, dalam kajian disertasinya mengatakan konsep hukum adat dan peradilan adat merupakan akar keadilan restoratif. Dengan mengutip Supomo tentang karakteristik hukum adat Indonesia, Eva Achayni Zulfa mencatat akar kedilan restoratif yang ditemukan dalam hukum adat, seperti :

a. Corak religius yang menempatkan hukum adat sebagai bentuk kesatuan batin masyarakat dalam suatu kesatuan (komunal);

b. Sifat komunal hukum adat menempatkan individu sebagai orang yang terikat dengan masyarakat. Seorang individu bukan sosok yang bebas dalam segala laku, karena dia dibatasi oleh norma yang telah berlaku baginya;

c. Tujuan persekutuan masyarakat adalah memelihara keseimbangan lahir batin antara individu, golongan dan lingkungan hidupnya. Tujuan ini pada dasarnya dipikul oleh masing-masing individu anggotanya demi pencapaian tujuan bersama;

d. Tujuan pemeliharaan keseimbangan lahir batin berpangkal pada pandangan ketertiban alam semesta (kosmos). Kepentingan masyarakat merupakan hubungan harmonis antara segala sesuatu sesuai dengan garis dan keseimbangan kosmos;

e. Pelanggaran terhadap hukum adat, merupakan pelanggaran terhadap ketertiban kosmos.

f. Jika garis kosmos tidak dijalani, walaupun oleh seorang individu, maka baik masyarakat maupun orang tersebut akan menderita, karena berada di luar garis kosmos yang ada. ${ }^{36}$

Dengan memperhatikan ciri hukum adat di atas terlihat bahwa keseimbangan dan keharmonisan masyarakat menjadi hal utama dalam karakteristik hukum adat. Hukum adat yang begitu memperhatikan keterkaitan

\footnotetext{
${ }^{36}$ Ahmad Ubbe, Peradilan Adat dan Keadilan Restoratif, Vol. 2 No. 2, Jurnal Rechtsvinding: Media Pembinaan Hukum Nasional berjudul Jakarta: Pusat Penelitian dan Pengembangan Sistem Hukum Nasional Badan Pembinaan Hukum Nasional Kementerian Hukum dan HAM RI, 2013, hlm. 165
} 
dan keterikatan individu dengan lingkungan sekitarnya juga menunjukkan bahwa hukum adat tidak berfokus pada pelaku tetapi terhadap akibat dari tindakan pelaku, dan ini merupakan ciri dari keadilan restoratif. Namun sangat disayangkan bahwa saat ini penerapan hukum adat dalam sistem peradilan hukum formal di Indonesia masih sangat minim bahkan terkesan keberadaannya berada di luar sistem hukum Nasional. Hal ini sejalan dengan pendapat dari Eva Achjani Zulfa yang menyatakan bahwa :

"Eksistensi peradilan adat kerap dipertanyakan. Hal ini disebabkan karena sistem dan mekanisme yang disebut sebagai peradilan adat seolah-olah berada di luar mekanisme hukum formal yang berlaku di Indonesia." 37

Apabila melihat dari pernyataan di atas, tidak heran apabila saat ini penerapan hukum nasional yang telah dikodifikasi lebih diutamakan dibandingkan penerapan hukum adat dalam sistem peradilan hukum di Indonesia. Hal itu dapat dipahami, terlebih di dalam sistem peradilan pidana mengenal asas "lex scripta" dan "lex carta", dimana asas "nullum delictum nulla poena sine privea lege poenali", melarang keberlakuan hukum yang tidak tertulis karena dianggap akan mengancam kepastian hukum yang diusung sebagai landasan utama keberlakuan hukum pidana. ${ }^{38}$

Walaupun demikian, peraturan perundang-undangan kita sebetulnya mengakui adanya keberadaan hukum adat. Seperti yang tertuang di dalam Undang-undang Dasar 1945 serta Undang-undang No. 48 tahun 2009 tentang Kekuasaan Kehakiman. Berikut pemaparannya :

\section{Undang-undang Dasar 1945}

Pasal 18B ayat (2)

"Negara mengakui dan menghormati kesatuan-kesatuan masyarakat hukum adat beserta hak-hak tradisionalnya sepanjang masih hidup dan

\footnotetext{
${ }^{37}$ Lihat Eva Achjani Zulfa, Supra no 25, hlm 1

38 Id.. hlm. 4
} 
sesuai dengan perkemabangan masyarakat dan prinsip Negara Kesatuan Republik Indonesia, yang diatur dalam undang-undang."

Pasal 32 ayat (1)

"Negara memajukan kebudayaan nasional Indonesia di tengah peradaban dunia dengan menjamin kebebasan masyarakat dalam memelihara dan mengembangkan nilai-nilai budayanya."

\section{Undang-undang No. 48 tahun 2009 tentang Kekuasaan Kehakiman}

Pasal 5 ayat (1)

"Hakim dan hakim konstitusi wajib menggali, mengikuti, dan memahami nilai-nilai hukum dan rasa keadilan yang hidup dalam masyarakat."

Pasal 50 ayat (1)

"Putusan pengadilan selain harus memuat alasan dan dasar putusan, juga memuat pasal tertentu dari peraturan perundang-undangan yang bersangkutan atau sumber hukum tak tertulis yang dijadikan dasar untuk mengadili."

Dengan memperhatikan dua Undang-undang di atas, sebetulnya dapat dilihat bahwa dengan diakuinya hukum adat di Indonesia, yang memiliki nilainilai dari akar keadilan restoratif, maka sebetulnya peluang penerapan keadilan restoratif dalam sistem peradilan pidana di Indonesia sangat terbuka.

Asas hukum pidana yang tidak memperbolehkan adanya ketidakpastian hukum dalam hukum tidak tertulis sekiranya bisa dihadapkan dengan ajaran sifat melawan hukum materiil. Menurut Barda Nawawi Arief, S.H sifat melawan hukum materiel adalah :

"Identik dengan melawan/bertentangan dengan hukum tidak tertulis atau hukum yang hidup (unwritten law/the living law), bertentangan dengan dengan asas-asas kapatutan sosial dalam masyarakat (termasuk tata susila dan hukum kebiasaan/adat). ${ }^{39}$

39 Barda Nawawi Arief, Pembaharuan Hukum Pidana Dalam Perspektif Kajian Perbandingan, PT. Citra Aditya Bakti, 2011, Bandung, hlm 27 
Perumusan asas legalitas formil dan legalitas materiil dalam konsep KUHP memperlihatkan bahwa memang kepastian hukum dan keadilan selalu dalam keadaan yang bersitegang secara filosofis. ${ }^{40}$ Prof. Dr. Barda Nawawi Arief mengemukakan bahwa perwujudan asas legalitas materiil merupakan implementasi ide keseimbangan dalam sumber hukum atau landasan legalitas untuk menyatakan suatu perbuatan sebagai tindak pidana dengan berdasarkan pada hukum tertulis. Artinya, perbuatan melawan hukum tidak hanya ditetapkan oleh hukum tertulis melainkan juga dalam hukum tak tertulis. ${ }^{41}$ Hal tersebut pun sejalan dengan pendapat dari Muladi yang menyatakan bahwa di dalam kondisi yang sangat pluralistik dan sebagaimana penduduk masih hidup di pedesaan, kiranya sangat bijaksana untuk menerapkan ajaran sifat melawan hukum materiel dan menempatkan asas-asas keadilan yang bersifat umum sebagai pasangan dari kepastian hukum. ${ }^{42}$

Dengan memperhatikan pemaparan di atas, menegaskan bahwa peluang untuk menerapkan keadilan restoratif dalam hukum pidana di Indonesia sangat terbuka. Adapun hal ini diperhatikan dari 3 (tiga) perspektif, yakni :

1. Historis, yakni bahwa sebelum Indonesia dijajah oleh Eropa dan kemudian Eropa memberlakukan dan mewariskan konsep hukum mereka di Indonesia, telah ada hukum adat. Diketahui bahwa hukum adat memiliki nilai-nilai dari akar keadilan restoratif dan hal ini tentu menjadi peluang karena hukum adat hingga saat ini masih diterapkan di Indonesia.

2. Sumber Hukum, keberadaan hukum adat diakui keberadaannya di dalam Undang-undang Dasar 1945 serta Undang-undang Kekuasaan Kehakiman.

3. Dibenarkan konsep penerapannya oleh ajaran hukum pidana, khususnya ajaran sifat melawan hukum materiel.

Dengan demikian melihat dari beberapa 3 (tiga) perspektif serta beberapa kasus yang menerapkan keadilan restoratif yang telah dijelaskan pada sub bagian

\footnotetext{
40 Reimon Supusesa, Supra no. 31, hlm 51

41 Id., hlm 52

42 Id., hlm 52
} 
sebelumnya, maka penerapan keadilan restoratif di Indonesia terbuka kemungkinan untuk diterapkan tidak hanya kepada kasus anak. Ditambah sebetulnya perlu diketahui pula bahwa konsep hukum adat sebetulnya telah menjadi inspirasi negara-negara lain dalam menyelesaikan permasalahan. pluralisme hukum adat di Indonesia yang tumbuh kembang secara dinamis mengikuti perkembangan masyarakatnya dengan tetap bertumpu pada karakteristik masyarakat adat dan pola pikir participerend coshmish ${ }^{43}$ menarik minat para pakar dari penjuru dunia untuk dijadikan objek penelitian. Pola pikir participerend coshmish mirip dengan pendekatan restoratif (restorative approach). Universitas Utrecht misalnya berupaya mendorong digunakannya musyawarah mufakat model masyarakat adat Melayu dalam menyelesaikan permasalahan yang terjadi. Salah satu hasil dalam upaya tersebut yakni munculnya arbitrase dan alternatif penyelesaian sengketa sebagai pilihan penyelesaian di luar pengadilan. Dimana konsep ini pun telah diterapkan di Indonesia melalui Undang-undang No. 30 tahun 1999 karena terinspirasi konsep dari Negara dengan common law system dalam menyelesaikan sengketa. Fakta ini semakin memberikan gambaran bahwa konsep serta pola pikir hukum adat masih sangat relevan untuk digunakan bahkan menjadi inspirasi bagi negara-negara lain untuk mengembangkan hukum guna memenuhi rasa keadilan masyarakat. 44

\section{Hambatan Penerapan Keadilan Restoratif di Indonesia}

Seperti yang disinggung sebelumnya bahwa terdapat peluang diterapkannya konsep keadilan restoratif pada hukum pidana Indonesia dilihat dari segi historis, sumber hukum ataupun teori dalam hukum pidana. Namun bukan berarti dengan adanya peluang tersebut tidak terdapat hambatan-

\footnotetext{
${ }^{43}$ Pola pikir participerend coshmish bertumpu pada pandangan bahwa alam semesta dengan segala isinya merupakan satu kesatuan yang harus senantiasa dijaga keutuhan dan keseimbangannya. Oleh karena itu setiap gangguan terhadap keseimbangan alam semesta perlu dipulihkan seperti sediakala.

${ }^{44}$ Intisari Lastuti Abubakar, Revitalisasi Hukum Adat Sebagai Sumber Hukum dalam Membangun Sistem Hukum Indonesia, Vol. 13 No. 2. Jurnal Dinamika Hukum, Fakultas Hukum Universitas Jenderal Soedirman Purwokerto Jawa Tengah, 2013, hlm. 321
} 
hambatan yang akan terjadi apabila konsep keadilan restoratif diterapkan di Indonesia. Hambatan-hambatan tersebut dapat dilihat dari segi sosial dan politik hukum pidana di Indonesia.

Pertama, apabila dilihat dari segi sosial penerapan keadilan restoratif di Indonesia akan mengalami hambatan yakni bahwa dewasa ini masyarakat Indonesia lebih menyukai dan condong terhadap pola 'penghukuman' untuk diterapkan kepada pelaku kejahatan. Lapas yang penuh dan banyak diisi oleh narapidana-narapidana yang kasusnya sampai pada tingkatan kasasi padahal tindak pidana yang dilakukan hanyalah tindak pidana ringan menunjukkan bahwa masyarakat Indonesia saat ini masih memiliki pola pikir memberikan 'penghukuman' kepada pelaku tindak pidana. Tentu hal ini bertentangan dengan nilai keadilan restoratif yang memiliki spirit bukan untuk menghukum, tetapi untuk memulihkan atau mengembalikan (restore) dengan memberikan tanggungjawab kepada seseorang yang melakukan tindakan menyimpang.

Potret di atas pun terlihat dari mulai ditinggalkannya penerapan hukum adat di Indonesia. Hukum adat yang memiliki akar nilai serta unsur-unsur keadilan restoratif saat ini dirasa kuno oleh masyarakat di Indonesia. Hal ini berbanding lurus dengan rendahnya angka daerah-daerah di Indonesia yang masih menerapkan hukum adat, sebut saja beberapa daerah di Indonesia yang masih mengutamakan penggunaan hukum adat yakni Papua, Bali, Toraja, Minangkabau, Kalimantan dan Jawa Tengah. ${ }^{45}$ Sehingga dengan demikian diperlukan sosialisasi dan pemahaman kepada seluruh lapisan masyarakat di Indonesia tentang konsep hukum yang sebetulnya tidaklah identik dengan penghukuman dan hal ini pun sesuai dengan semangat Pancasila sila ke-4 terkait permusyawaratan mufakat.

Kedua, hambatan yang akan terjadi apabila konsep keadilan restoratif diterapkan sebagai bagian dari hukum pidana di Indonesia yakni dilihat dari segi

\footnotetext{
45 Septa Candra, Restorative Justice: Suatu Tinjauan Terhadap Pembaharuan Hukum Pidana di Indonesia. Vol. 2 No. 2, Jurnal Rechtsvinding: Media Pembinaan Hukum Nasional berjudul Jakarta: Pusat Penelitian dan Pengembangan Sistem Hukum Nasional Badan Pembinaan Hukum Nasional Kementerian Hukum dan HAM RI, 2013, hlm. 165
} 
politik hukum pidana. Saat ini penerapan hukum di Indonesia nampak mengalami dualisme hukum, yakni hukum nasional dan hukum adat. Namun perlu diperhatikan bahwa dengan adanya Undang-undang Dasar 1945 dan Undangundang Kehakiman sebetulnya menegaskan bahwa hukum adat adalah bagian dari hukum nasional. Pemahaman bahwa hukum adat bukanlah bagian dari hukum nasional dikarenakan hukum adat yang bukanlah hukum tertulis tidak memberikan dan menjamin kepastian hukum sehingga memberikan kesan bahwa penerapan hukum non-adat dirasa lebih memberikan keadilan. Selo Soepardjan pun mengklasifikasikan bahwa masyarakat pra modern atau modern dicirikan dengan hukum yang berlaku yaitu hukum tertulis. ${ }^{46}$ Sehingga pemikiran demikian menjadi hambatan tersendiri karena tidak menutup kemungkinan pihak-pihak yang menyelesaikan kasusnya dengan konsep keadilan restoratif, salah satu pihak melanjutkan kasus terkait ke hukum pidana formal.

\section{Penutup}

Apabila melihat dari konsep keadilan restoratif, hukum adat di Indonesia memiliki nilai serta akar dari konsep keadilan restoratif. Keadilan restoratif dan hukum adat memiliki tujuan yang sama yakni untuk pemulihan serta menyeimbangkan kembali kondisi masyarakat akibat adanya prilaku menyimpang, dengan bukan bertujuan untuk memberikan hukuman. Hukum adat yang telah berkembang sebelum Indonesia dijajah oleh Eropa menunjukkan bahwa penerapan keadilan restoratif dapat diperluas tidak hanya diterapkan pada kasus anak. Walaupun saat ini hukum adat sudah mulai ditinggalkan di banyak daerah di Indonesia, namun tidak berarti hal ini tidak dapat dikembangkan kembali, pemahaman masyarakat, sistem hukum pidana serta sistem peradilan yang lebih mengedepankan penerapan hukum adat menjadi faktor penting untuk mengembangkan kembali hukum adat di Indonesia. Hal ini diperlukan karena

\footnotetext{
${ }^{46}$ Soleman B. Taneko, Hukum Adat : Suatu Pengantar Awal dan Prediksi Masa Mendatang, Eresco, Bandung, 1987, hlm. 100
} 
untuk mengubah pola pikir masyarakat Indonesia yang masih menyikapi pelaku prilaku menyimpang dengan penghukuman yang bertujuan untuk pembalasan dendam, bukan untuk pemulihan. Persoalan baru justru akan muncul apabila hal tersebut terus menerus dibiarkan, seperti munculnya residivis dikarenakan penghukuman tidak memberikan efek jera serta penuhnya lapas diakibatkan banyaknya narapidana. Hal tersebut tidak saja memberikan kekhawatiran kepada masyarakat tetapi juga merugikan Negara dengan beban mengakomodir kebutuhan dasar seluruh narapidana.

Perundang-undangan di Indonesia yang mengakui nilai-nilai yang ada di masyarakat serta adanya ajaran sifat melawan hukum materiel dalam hukum pidana dapat menjadi tonggak awal untuk menerapkan konsep keadilan restoratif dalam menyikapi perbuatan dan akibat dari tindakan yang menyimpang. Penerapan keadilan restoratif pada beberapa contoh kasus dapat menjadi contoh penerapan keadilan restoratif tidak hanya kepada anak-anak, tetapi juga dapat diterapkan pula pada orang dewasa. Apabila hal ini dapat dikembangkan, kekhawatiran masyarakat akan ketertiban umum dan beban negara akibat pembiayaan lapas yang semakin penuh akan tereduksi seiring dengan pola pikiran masyarakat Indonesia yang mengedepankan keharmonisan selayaknya nilai luhur yang dijunjung bangsa Indonesia.

\section{Daftar Pustaka}

\section{Buku :}

Allison Morris and Warren Young, Restorative Justice: Philosophy to practice, USA, Ashgate, Dartmouth, 2000

Barda Nawawi Arief, Pembaharuan Hukum Pidana Dalam Perspektif Kajian Perbandingan, PT. Citra Aditya Bakti, Bandung, 2011

E.Y, Kanter dan S.R Sianturi, Asas-asas Hukum Pidana di Indonesia dan Penerapannya, Storia Grafika, Jakarta, 2012 
Justice Nicola Pain, dkk. Restorative Justice for Environmental Crime: an Antipodean Experince, International Union for Conservation of Nature Academy of Environmental Law Colloquium, Oslo, Norway, 2016

Kathleen Daly, Restorative Justice: Philosophy to practice, Ashgate, Dartmouth, USA, 2000

Marwan Effendy, Teori Hukum dari Perspektif Kebijakan, Perbandingan dan Harmonisasi Hukum Pidana, Referensi, Jakarta, 2014

M. Hamdan, Politik Hukum Pidana, PT. Raja Grafindo Persada, Jakarta, 1997

Mohammad Kemal Dermawan dan Mohammad Irvan Oli'i, Sosiologi Peradilan Pidana, FISIP UI dan Yayasan Obor Indonesia, Jakarta, 2015

Muladi Proyeksi Hukum Pidana Materiil Indonesia di Masa Datang, Universitas Diponegoro, Semarang, 1990

Seumas Miller and John Blackler, Restorative Justice: Philosophy to practice, Ashgate, USA, Dartmouth, 2000

Soleman B. Taneko, Hukum Adat: Suatu Pengantar Awal dan Prediksi Masa Mendatang, Eresco, Bandung, 1987

St, Laksanto Utomo. Hukum Adat, Rajagrafindo Persada, Depok, 2016

Tim Departemen Kriminologi FISIP UI, Viktimologi Reparasi dan Kompensasi Korban Dalam Restorative Justice System, Lembaga Perlindungan Saksi dan Korban (LPSK), Jakarta, 2011

Jurnal :

Ahmad Ubbe, Peradilan Adat dan Keadilan Restoratif, Vol. 2 No. 2, Jurnal Rechtsvinding : Media Pembinaan Hukum Nasional berjudul Jakarta: Pusat Penelitian dan Pengembangan Sistem Hukum Nasional Badan Pembinaan Hukum Nasional Kementerian Hukum dan HAM RI, 2013

Elwi Danil, Konstitusionalitas Penerapan Hukum Adat dalam Penyelesaian Perkara Pidana. Vol.9 No 3. Jurnal Konstitusi. Jakarta: Kepaniteraan dan Sekretariat Jenderal Mahkamah Konstitusi Republik Indonesia, 2012

Lastuti Abubakar, Revitalisasi Hukum Adat Sebagai Sumber Hukum dalam Membangun Sistem Hukum Indonesia. Vol. 13 No. 2. Jurnal Dinamika Hukum.Purwokerto :Fakultas Hukum Universitas Jenderal Soedirman Purwokerto Jawa Tengah, 2013

Reimon Supusesa, Eksistensi Hukum Delik Adat Dalam Perspektif Pembaharuan Hukum Pidana di Maluku Tengah. Vol. 24 No. 1. Mimbar Hukum. Yogyakarta : Universitas Gadjah Mada, 2012

S. Atalim. Keadilan Restoratif Sebagai Kritik Inheren Terhadap Pengadilan LegalKonvensional, Vol. 2 No. 2, Jurnal Rechtsvinding : Media Pembinaan Hukum Nasional berjudul Jakarta : Pusat Penelitian dan Pengembangan Sistem Hukum Nasional Badan Pembinaan Hukum Nasional Kementerian Hukum dan HAM RI, 2013

Septa Candra. Restorative Justice : Suatu Tinjauan Terhadap Pembaharuan Hukum Pidana di Indonesia. Vol. 2 No. 2, Jurnal Rechtsvinding : Media Pembinaan 
Hukum Nasional berjudul Jakarta: Pusat Penelitian dan Pengembangan Sistem Hukum Nasional Badan Pembinaan Hukum Nasional Kementerian Hukum dan HAM RI, 2013

S. Sahabuddin, Jurnal Dinamika Hukum : Reorientasi Kebijakan Kriminal Dalam Menyelesaikan asus Ringan (Dari Due Process Model ke Reintegrative Model). Purwokerto: Fakultas Hukum Universitas Jenderal Soedirman, 2014

Yanis Maladi, Eksistensi Hukum Adat Dalam Konstitusi Negara Pasca amandemen. Vol. 22 No. 3. Mimbar Hukum. Yogyakarta: Universitas Gadjah Mada, 2010

\section{Artikel :}

Eva Achjani Zulfa. Eksistensi Peradilan Adat Dalam Sistem Hukum Pidana Indonesia.http://bphn.go.id/data/documents/lampiran makalah dr. eva a chjani, sh.,mh.pdf, hlm. 1, diakses 3 Mei 2018

\section{Peraturan Perundang-undangan:}

Undang-undang Dasar 1945

Undang-undang No. 23 tahun 2002 tentang Perlindungan Anak yang kemudian terdapat perubahan yang tercantum di dalam Undang-undang No. 35 tahun 2014 tentang perlindungan anak

Undang-undang No. 48 tahun 2009 tentang Kekuasaan Kehakiman

\section{Internet :}

Berita hukumonline Hakim Perintahkan AQJ Dikembalikan Kepada Orang Tua, diakses 30 April 2018, pkl. 23.11

Berita detiknews. Polisi Pakai Restorative Justice di Kasus Bocah Pembakar Ruang Kelas di Sukoharjo. diakses 30 April 2018, pkl 23.15

Berita CNN Indonesia Penjara Penuh Sesak, Ratusan Kepala Lapas Mengadu ke Yasonna, diakses 2 Juni 2018, pkl 11.33

Berita Hukum Online. MA Keluhkan Pelaksanaan Perma Tipiring, diakses 1 Maret 2018, pkl.00:14 